\title{
Real-time reverse transcription polymerase chain reaction development for rapid detection of Tomato brown rugose fruit virus and comparison with other techniques
}

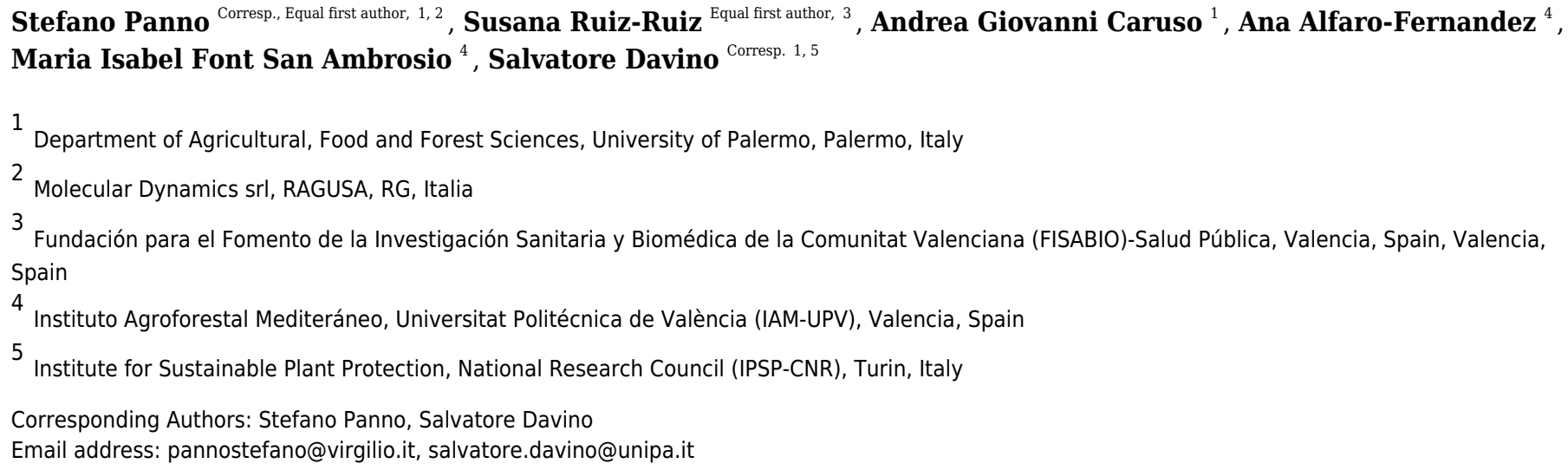

Background. Tomato brown rugose fruit virus (ToBRFV) is a highly infectious tobamovirus that causes severe disease in tomato (Solanum lycopersicum L.) crops. In Italy, the first ToBRFV outbreak occurred in 2018 in several provinces of the Sicily region. ToBRFV outbreak represents a serious threat for tomato crops in Italy and the Mediterranean Basin. Methods. Molecular and biological characterisation of the Sicilian ToBRFV ToB-SIC01/19 isolate was performed, and a sensitive and specific Real-time RT-PCR TaqMan MGB probe method was developed to detect ToBRFV in infected plants and seeds. Moreover, four different sample preparation procedures (immunocapture, total RNA extraction, direct crude extract and leaf-disk crude extract) were evaluated. Results. The Sicilian isolate ToB-SIC01/19 (6,391 nt) showed a strong sequence identity with the isolates TBRFVP12-3H and TBRFV-P12-3G from Germany, Tom1-Jo from Jordan and TBRFV-IL from Israel. The ToB-SIC01/19 isolate was successfully transmitted by mechanical inoculations in Solanum lycopersicum L. and Capsicum annuum L., but no transmission occurred in Solanum melongena L.. The developed Real-time RT-PCR, based on the use of a primer set designed on conserved sequences in the ORF3, enabled a reliable quantitative detection. This method allowed clear discrimination of ToBRFV from other viruses belonging to the genus Tobamovirus, minimising false-negative results. Using immunocapture and total RNA extraction procedures, Real-time RT-PCR and end-point RT-PCR gave the same comparable results. Using direct crude extracts and leaf-disk crude extracts, end-point RTPCR was unable to provide a reliable result. This developed highly specific and sensitive Real-time RT-PCR assay will be a particularly valuable tool for early ToBRFV diagnosis, 
optimising procedures in terms of costs and time. 


\section{Real-time reverse transcription polymerase chain}

2 reaction development for rapid detection of Tomato

3 brown rugose fruit virus and comparison with other

4 techniques

6 Stefano Panno ${ }^{1,2}$, Susana Ruiz-Ruiz ${ }^{3}$, Andrea Giovanni Caruso ${ }^{1}$, Ana Alfaro-Fernandez $z^{4}$, Maria

7 I. Font San Ambrosio ${ }^{4}$, Salvatore Davino 1,5

8 'Department of Agricultural, Food and Forestry Sciences, University of Palermo, Palermo, Italy

$9 \quad{ }^{2}$ MolecuarDynamics srl, Via M. Rapisardi, 72 Ragusa, Italy

10 3Fundación para el Fomento de la Investigación Sanitaria y Biomédica de la Comunitat

11 Valenciana (FISABIO)-Salud Pública, Valencia, Spain

12 Instituto Agroforestal Mediteráneo, Universitat Politècnica de València (IAM-UPV), Camino de

13 Vera s/n, 46022 Valencia (Spain).

$14{ }^{5}$ Institute for Sustainable Plant Protection, National Research Council (IPSP-CNR), Turin, Italy

Corresponding Authors:

Salvatore Davino

Viale delle Scienze, building 5, Palermo, 90128, Italy

Email address: salvatore.davino@unipa.it

Stefano Panno

Viale delle Scienze, building 5, Palermo, 90128, Italy

Email address: stefano.panno@unipa.it

Kyewords: Fast detection, ToBRFV, Real-time RT-PCR

\section{Abstract}

Background. Tomato brown rugose fruit virus (ToBRFV) is a highly infectious tobamovirus that causes severe disease in tomato (Solanum lycopersicum L.) crops. In Italy, the first ToBRFV outbreak occurred in 2018 in several provinces of the Sicily region. ToBRFV outbreak represents a serious threat for tomato crops in Italy and the Mediterranean Basin.

Methods. Molecular and biological characterisation of the Sicilian ToBRFV ToB-SIC01/19 isolate was performed, and a sensitive and specific Real-time RT-PCR TaqMan MGB probe method was developed to detect ToBRFV in infected plants and seeds. Moreover, four different sample preparation procedures (immunocapture, total RNA extraction, direct crude extract and leaf-disk crude extract) were evaluated. Results. The Sicilian isolate ToB-SIC01/19 (6,391 nt) showed a strong sequence identity with the isolates TBRFV-P12-3H and TBRFV-P12-3G from Germany, Tom1-Jo from Jordan and 
inoculations in Solanum lycopersicum L. and Capsicum annuum L., but no transmission occurred in Solanum melongena L.. The developed Real-time RT-PCR, based on the use of a primer set designed on conserved sequences in the ORF3, enabled a reliable quantitative detection. This method allowed clear discrimination of ToBRFV from other viruses belonging to the genus Tobamovirus, minimising false-negative results. Using immunocapture and total RNA extraction procedures, Real-time RT-PCR and end-point RT-PCR gave the same comparable results. Using direct crude extracts and leaf-disk crude extracts, end-point RT-PCR was unable to provide a reliable result. This developed highly specific and sensitive Real-time RT-PCR assay will be a particularly valuable tool for early ToBRFV diagnosis, optimising procedures in terms of costs and time.

\section{Introduction}

Tomato (Solanum lycopersicum L.) is one of the most important horticultural crops worldwide. Indeed in 2017, more than 182 million tons of tomato have been produced $(F A O, 2017)$. China is the most important tomato producer (59 million tons), followed by India, Turkey and United States, while Italy and Spain are the major tomato producers in Europe (over 6 million and 5 million tons, respectively) ( $F A O, 2017)$. In Italy, greenhouse tomato production is mainly developed in the southern regions, and Sicily produces about $40 \%$ of national production (Agri ISTAT, 2017). In the last years, emerging viral diseases have been an important limiting factor for many crop production systems, such as tomato crops, causing considerable economic losses (Hanssen et al., 2010). Greenhouse tomato production in Italy is affected by important losses that are caused by several different viruses: Pepino mosaic virus (PepMV) (Davino et al., 2008; Davino et al., 2017a; Tiberini et al., 2011), Tomato mosaic virus (ToMV), Tomato spotted wilt virus (TSWV) (Panno et al., 2012), Tomato leaf curl New Delhi virus (ToLCNDV) (Panno et al., 2019a), Tomato yellow leaf curl virus (TYLCV) - Tomato yellow leaf curl Sardinia virus (TYLCSV) and their recombinants (Davino et al., 2009, 2012, Panno et al., 2018) and Tomato brown rugose fruit virus detected at the end of 2018 (ToBRFV) (Panno et al., 2019b). The international trade globalisation and the free commodities movement complicate the control of pathogens in the free trade area of the Mediterranean Basin. In this context, the control of seed-transmitted pathogens is extremely difficult. This is the case of the recent ToBRFV outbreak in Sicily, which was probably introduced into the island either through infected seeds or through infected fruits and their subsequent manipulation.

ToBRFV is a member of the genus Tobamovirus, family Virgaviridae. Tobamovirus is probably the largest genus of this family for numbers of species (King et al., 2011). Tobamoviruses are the only members of this family that have an undivided genome. ToBRFV has a single-stranded positive-sense RNA (gRNA) of $\sim 6,400$ nucleotides (nt), with a typical tobamoviruses organisation that consists in 4 open reading frames (ORFs) encoding two replication-related proteins of 126 and $183 \mathrm{kDa}$, in which the second protein is expressed by the partial suppression of the stop codon (ORF1 and ORF2), the movement protein (MP) of $30 \mathrm{kDa}$ (ORF3) and the coat 
78 protein $(\mathrm{CP})$ of $17.5 \mathrm{kDa}(\mathrm{ORF} 4)$, which are expressed via the 3'-coterminal sub-genomic RNAs 79 (sgRNAs) (Salem et al., 2016).

80 ToBRFV was described in 2016 for the first time in Jordan by Salem and co-workers (2016) on 81 greenhouse tomato plants, and in 2017 in Israel on tomato plants harbouring the $T m-2^{2}$ gene 82 (Luria et al., 2017). Afterwards, ToBRFV was detected in Mexico in tomato and pepper crops 83 (Cambrón-Crisantos et al., 2018) and after it spread to Germany, United States (California), 84 Palestine, Italy and Turkey (Menzel et al., 2019; Ling et al., 2019; Alkowni et al., 2019; Panno et 85 al., 2019b; Fidan et al., 2019).

86 ToBRFV symptoms are typical of the tobamoviruses infection and consist of tomato leaves 87 interveinal yellowing and deformation, mosaic staining, young leaves deformation and necrosis, sepal necrosis and deformation, young fruits discolouration, deformation and necrosis. For this reason ToBRFV represents a very dangerous problem for tomato crops in all the regions where tomato is cultivated, due to the ability of the virus to be transmitted by contact through

91

92

93

94 95

96

97

98

99

100

101

102

103

104

105

106

107

108

109

110

111

112

113

114

115

116

117 contaminated tools, hands, clothing, direct plant-to-plant contact, propagation material (grafts, cuttings), bumblebees and seeds (Levitzky et al., 2019).

The aim of the present study was to characterise the virus found in Italy and to develop a sensitive, specific and economical method to detect ToBRFV in infected plants and seeds.

\section{Materials \& Methods}

\section{Source of viral material}

In October 2018, virus-like symptoms typical of tobamovirus infection were observed in tomato greenhouses in the Ragusa province (Sicily - Italy). These symptoms were very similar to those described by Salem and co-workers (2016) who identify a new tobamovirus, named Tomato brown rugose fruit virus, which overcomes the $T m-2^{2}$ resistance gene. The symptoms consisted of severe mosaic, young leaves deformation and necrosis, fruits discolouration and marbling and sepals' necrosis (Figure 1).

The samples used in this study were collected in four different areas of Sicily, in the provinces of Agrigento, Caltanissetta, Ragusa and Siracusa. 15 samples were collected from two different greenhouses of each area, according to the following scheme: 3 plants rows were selected from 60 total rows (one row every 20) and five samples were taken from each selected row (one sample every 10 plants) (Panno et al., 2019b). Sampling was repeated three times: the first sampling in October 2018, the second in December 2018 and the third at the end of February 2019. A total of 360 samples were collected and marked by GPS using PLANTHOLOGY mobile application (Davino et al., 2017b).

\section{Screening of ToBRFV using end-point RT-PCR}

One-step end-point RT-PCR was performed in $25 \mu \mathrm{l}$ (final volume) containing $2 \mu \mathrm{l}$ of total RNA extract, $20 \mathrm{mM}$ Tris- $\mathrm{HCl}$ (pH 8.4), $50 \mathrm{mM} \mathrm{KCl}, 3 \mathrm{mM} \mathrm{MgCl} 2,0.4 \mathrm{mM}$ dNTPs, $1 \mathrm{mM}$ of the forward primer ToBRFV-F-5722 and $1 \mathrm{mM}$ of the reverse primer ToBRFV-R-6179 (Panno et al., 2019b), 4U of RNaseOut, $20 \mathrm{U}$ of superscript II reverse transcriptase-RNaseH and $2 \mathrm{U}$ of Taq 
118 DNA polymerase (Thermo Fisher Scientific, Waltham, Massachusetts, USA). RT-PCR was

119

120

121

122

123

124

125

126

127

128

129

130

131

132

133

134

135

136

137

138

139

140

141

142

143

144

145

146

147

148

149

150

151

152

153

154

155

156

157

carried out in a MultiGene OptiMax thermal cycler (Labnet International Inc, Edison, NJ, USA)

according to the following cycling conditions: $42{ }^{\circ} \mathrm{C}$ for $45 \mathrm{~min}, 95^{\circ} \mathrm{C}$ for $5 \mathrm{~min}$; 40 cycles of 30 sec at $95{ }^{\circ} \mathrm{C}, 30 \mathrm{sec}$ at $55^{\circ} \mathrm{C}, 30 \mathrm{sec}$ at $72{ }^{\circ} \mathrm{C}$ and a final elongation of $10 \mathrm{~min}$ at $72{ }^{\circ} \mathrm{C}$. The obtained DNA products of expected size were confirmed by electrophoretic separation in a $1.5 \%$ agarose gel and staining with Sybrsafe (Thermo Fisher Scientific, MA, USA).

\section{Mechanical transmission}

The Sicilian ToBRFV ToB-SIC01/19 isolate was mechanically inoculated into three plants of different hosts (Solanum lycopersicum L., Solanum melongena L. and Capsicum annuum L.) for subsequent biological characterisation. Plants were grown on a sterilised soil in an insect-proof glasshouse, with a photoperiod of $14 \mathrm{~h}$ of light and a target air temperature set at $28 / 20^{\circ} \mathrm{C}$ day/night. The symptoms were reported weekly and the presence of ToBRFV was evaluated at 30 dpi by RT-PCR as previously described.

\section{Full genome sequencing}

Full genome sequencing was performed using the primer walking strategy (Knippers and Alpert, 1999) with the specific and overlapping primers reported by Luria and coworkers (2017). Four pairs of primers targeting ToBRFV conserved sequences were included to obtain the full genome sequence: FTobGEN, RTobGEN, F1-R1572, F1534-R3733 and F4587-R6392.

RT-PCR was performed in a MultiGene OptiMax thermal cycler (Labnet International Inc, Edison, NJ, USA) according to the conditions reported by Luria et al. (2017). The obtained products were confirmed by electrophoretic separation in a $1.5 \%$ agarose gel and visualized using Sybrsafe staining. The products were subsequently purified with the Ultraclean 96 PCR Cleanup Kit (Qiagen, Hilden, Germany) according to the manufacturer's instructions and cloned using the TA-cloning system (Promega, WIS, USA). The five obtained plasmids were sequenced in both directions using an ABI PRISM 3100 DNA sequence analyser (Applied Biosystems, CA, USA).

To obtain the 3' and 5' terminal region sequences, a rapid amplification of cDNAs RACE was performed with the following primers: R-Ex-480, R-In-408, F-Ex-5931 and F-In-6041 (Luria et al., 2017), using a SMARTer® RACE 5'/3' Kit (Takara Bio, USA) according to the manufacturer's instructions. The obtained DNA products were cloned using the TA-cloning system (Promega, WIS, USA) and the five obtained plasmids were sequenced. All the obtained sequences of each region were assembled using the program Contig implemented in Vector NTI Advance 11.5 software (Invitrogen, CA, USA) to obtain the de novo full-length sequence of ToBRFV genome.

\section{Primer and Taqman $®$ MGB probe design}

Four full-length genomic sequences of Tomato brown rugose fruit virus retrieved from GenBank (accession nos. MK133095, MK133093, KT383474 and KX619418) and a sequence assembled

Peer) reviewing PDF | (2019:08:40110:1:1:NEW 18 Sep 2019) 
158 in our lab during this work were aligned using ClustalX2 program (Larkin et al., 2007) in order

159

160

161

162

163

164

165

166

167

168

169

170

171

172

173

174

175

176

177

178

179

180

181

182

183

184

185

186

187

188

189

190

191

192

193

194

195

196

197

to design 5 primer pairs targeting only conserved sequences.

The obtained primers were tested in vitro with the Primer-BLAST algorithm

(https://www.ncbi.nlm.nih.gov/tools/primer-blast/index.cgi) to evaluate the possibility of specific hybridisation with other organisms. The same primers were also tested using Vector NTI Advance 11.5 software (Invitrogen, CA, USA) with the complete sequence of other tobamoviruses to understand their affinity percentages. The included tobamoviruses were: Bell pepper mottle virus (1 sequence), Brugmansia mild mottle virus (1 sequence), Obuda pepper virus (2 sequences), Paprika mild mottle virus (2 sequences), Pepper mild mottle virus (13 sequences), Rehmannia mosaic virus (6 sequences), Tobacco mild green mosaic virus ( 7 sequences), Tobacco mosaic virus (10 sequences), Tomato mottle mosaic virus (5 sequences) and Tomato mosaic virus (10 sequences).

The obtained five primer pairs were tested by Real-time RT-PCR with SYBR green, in order to understand which primer pair has the lowest Ct value. Real-time RT-PCR was performed in a Q2plex HRM Platform Thermal Cycler (Qiagen, Hilden, Germany). The mixture consists in a 20 $\mu 1$ final volume containing $1 \mu 1$ of total RNA extract (ToB-SIC01/19) with $\sim 10 \mathrm{ng} \mathrm{RNA} / \mu 1$ concentration, $1 \mu 1$ of $1 \mathrm{mM}$ of each primer, $10 \mu 1$ of Master mix QuantiNOVA XX (Qiagen, Hilden, Germany) and $\mathrm{H}_{2} \mathrm{O}$ DEPC to reach the final volume.

Healthy tomato plant RNA and water were used as control samples. Each sample was analysed twice. Cycling conditions included reverse transcription at $48{ }^{\circ} \mathrm{C}$ for $10 \mathrm{~min}$, incubation at $95{ }^{\circ} \mathrm{C}$ for $5 \mathrm{~min}, 45 \mathrm{cycles}$ of $95^{\circ} \mathrm{C}$ for $2 \mathrm{sec}$ and $60^{\circ} \mathrm{C}$ for $20 \mathrm{sec}$ and fluorescence was measured at the end of each cycle. Melting curve steps were added at the end of RT-PCR as following: $95^{\circ} \mathrm{C}$ for $1 \mathrm{~min}, 40^{\circ} \mathrm{C}$ for $1 \mathrm{~min}, 70{ }^{\circ} \mathrm{C}$ for $1 \mathrm{~min}$ and a temperature increase to $95^{\circ} \mathrm{C}$ at $0.5^{\circ} \mathrm{C} / \mathrm{s}$ to record the fluorescence.

A specific ToBRFV TaqMan ${ }^{\circledR}$ MGB probe (Eurofins Genomics, Luxembourg) was designed in a conserved domain within the region encompassed by the primers. The probe, with a length of 22 nucleotides, was 5'-labelled with the reporter dye FAM (6-carboxyfluorescein) and 3'labelled with a non-fluorescent quencher (MGB NFQ). TaqMan MGB probes include a minor groove binder (MGB) moiety at the 3' end, which increases the melting temperature (Tm) of the probe and stabilises the probe-target hybrids. Consequently, MGB probes can be significantly shorter than traditional probes, providing better sequence discrimination and flexibility to accommodate more targets. The predicted Tm values for ToBRFV primers and probe were 59-60 ${ }^{\circ} \mathrm{C}$ and $67{ }^{\circ} \mathrm{C}$, respectively, calculated with the prediction tool provided by Primer Express Software v3.0.1. (Thermo Fisher Scientific, MA, USA). The sequences included in this study are reported in Table S1.

\section{ToBRFV genotype-specific Real-time RT-PCR assay with TaqMan MGB probe}

The Real-time RT-PCR assay with TaqMan MGB probe was performed in a Rotor-Gene Q2plex HRM Platform Thermal Cycler (Qiagen, Hilden, Germany) in a reaction mix of $12 \mu \mathrm{l}$ final volume, containing $1 \mu \mathrm{l}$ of total RNA extract with the concentration of $\sim 10 \mathrm{ng} \mathrm{RNA} / \mu \mathrm{l}, 0.5 \mu \mathrm{M}$

Peer) reviewing PDF | (2019:08:40110:1:1:NEW 18 Sep 2019) 
198

199

200

201

202

203

204

205

206

207

208

209

210

211

212

213

214

215

216

217

218

219

220

221

222

223

224

225

226

227

228

229

230

231

232

233

234

235

236

237

of the forward primer ToB5520F and the reverse primer ToB5598R (the primer set that yielded the most sensitive detection for all ToBRFV isolates in any type of tissue providing the lowest $\mathrm{Ct}$ values), $0.25 \mu \mathrm{M}$ of TaqMan MGB probe, $0.5 \mu \mathrm{l}$ of RNase Inhibitor (Applied Biosystems), $6 \mu 1$ of 2x QuantiNova Probe RT-PCR Master Mix, $0.2 \mu 1$ of QN Probe RT-Mix and $\mathrm{H}_{2} \mathrm{O}$ DEPC water to reach final volume.

The total RNA extracts used to perform this assay were obtained from five plants infected with ToBRFV and from eight tomato plants infected with Cucumber green mottle virus (CGMV), Paprika mild mottle virus (PaMMV), Pepper mild mottle virus (PMMV), Tobacco mild green mosaic virus (TMGMV), Tobacco mosaic virus (TMV), Tomato mottle mosaic virus (ToMMV), Tomato mosaic virus (ToMV) and Zucchini green mottle mosaic virus (ZGMMV). Each sample was analysed in duplicate in two independent Real-time RT-PCR assays. The control samples in each run included total RNA from a healthy tomato plant, water instead of sample and at least two RNA transcript dilutions of the standard curve (see below). The probe annealed specifically in an internal region of the PCR product amplified with primers

ToB5520F-ToB5598R. After binding, the probe is cleaved by the 5' exonuclease activity of the DNA polymerase, which releases the reporter molecule away from the quencher, allowing the reporter dye to emit its characteristic fluorescence. The TaqMan MGB probes incorporate an NFQ to absorb the (quench) signal from the fluorescent dye label at the 3' end of the probe. The properties of the NFQ combined with the length of the MGB probe result in lower background signal than with no-MGB NFQ probes. Lower background means increased sensitivity and precision. The cycling conditions consisted in reverse transcription at $45^{\circ} \mathrm{C}$ for $10 \mathrm{~min}$, enzyme denaturation at $95^{\circ} \mathrm{C}$ for $10 \mathrm{~min}$, and 45 cycles of $95{ }^{\circ} \mathrm{C}$ for $5 \mathrm{sec}$ and $60^{\circ} \mathrm{C}$ for $60 \mathrm{sec}$ with fluorescence measured at the end of each cycle. The mean (X) $\mathrm{Ct}$ value and the standard deviation (SD) for each tomato sample were calculated from the four Ct obtained values.

\section{Standard curve}

An external standard curve was generated to determine the sensitivity of the Real-time RT-PCR protocol with the TaqMan MGB probe. Serial dilutions of an in vitro synthesised positive-sense RNA transcript of the selected gRNA region were amplified using the Real-time RT-PCR TaqMan MGB assay. The template for the in vitro transcription was obtained by conventional RT-PCR amplification using total RNA extract from a tomato petiole infected with the just characterised ToBRFV ToB-SIC01/19 isolate. The obtained DNA product was cloned in the commercial pGEM-T vector, linearized with SalI enzyme and transcribed in vitro with the T7 RNA polymerase (New England Biolab, MA, USA) following the manufacturer's instructions. Transcripts were purified with RNaid Spin kit (Bio101, CA, USA), treated twice with RNase free DNase (Turbo DNA-free from Ambion) and their concentration was determined in duplicate with NanoDrop 1000 spectrophotometer (Thermo Fisher Scientific, MA, USA).

Ten-fold serial dilutions of the transcript in healthy tomato tRNA extract $(10 \mathrm{ng} / \mu \mathrm{l})$ containing $10^{10}$ to $10^{1}$ copies were used in the Real-time RT-PCR TaqMan MGB probe assay. The assay

Peer) reviewing PDF | (2019:08:40110:1:1:NEW 18 Sep 2019) 
238

239

240

241

242

243

244

245

246

247

248

249

250

251

252

253

254

255

256

257

258

259

260

261

262

263

264

265

266

267

268

269

270

271

272

273

274

275

276

277

was performed with and without the reverse transcriptase, to ensure the absence of DNA template in transcript preparations.

The RNA transcript concentration (pmol) in each dilution was calculated with the formula: micrograms of transcript RNA $\times(106 \mathrm{pg} / 1 \mu \mathrm{g}) \times(1 \mathrm{pmol} / 340 \mathrm{pg}) \times(1 /$ number of bases of the transcript), and the number of RNA copies was calculated using this concentration value and Avogadro's constant. The standard curve was obtained plotting the threshold cycle $(\mathrm{Ct})$ values from two independent assays with four replicates per standard dilution versus the logarithm of the RNA concentration dilution. The amplification efficiency was calculated from the slope of the corresponding curve using the formula $10^{(-1 / \text { slope of the standard curve })}$, or the same formula $\times 100$ (when given as a percentage value).

\section{Different methods for sample preparation and comparison of different ToBRFV detection techniques}

Four different procedures of sample preparation were evaluated using 40 samples from the 360 samples that were analysed previously by end-point RT-PCR (10 per province), the just characterised isolate ToB-SIC01/19 and a negative-tomato control plant. The obtained results were also compared by DAS-ELISA and end-point RT-PCR.

1) Immunocapture in Real-time PCR tubes: Multiwell plates for Real-time PCR were incubated at $37^{\circ} \mathrm{C}$ for $1 \mathrm{~h}$ with $100 \mu \mathrm{l}$ of polyclonal antibody for Tobacco mosaic virus (TMV) (AGDIA, IN, USA) diluted 1:200 in a coating buffer (sodium carbonate anhydrous $1.59 \mathrm{~g}$, sodium bicarbonate $2.93 \mathrm{~g}$, sodium azide $0.2 \mathrm{~g}$ in $1 \mathrm{~L}$ of distilled water, $\mathrm{pH} 9.6$ ). As reported by manufacture's protocol, this antibody reacts with a variety of viruses from the Tobamovirus genus, such as Cucumber green mild mottle virus (CGMMV), Kyuri green mottle mosaic virus (KGMMV), Pepper mild mottle virus (PMMoV), Tobacco mosaic virus (TMV), Tomato brown rugose fruit virus (ToBRFV) and Tomato mosaic virus (ToMV). After incubation, three washing steps were performed. $100 \mu \mathrm{l}$ of sap extract were obtained grinding the petioles in extraction buffer (sodium sulphite anhydrous $1.3 \mathrm{~g}$, polyvinylpyrrolidone (PVP) MW 24-40,000 $20 \mathrm{~g}$, powdered egg (chicken) albumin, Grade II $2 \mathrm{~g}$, Tween-20 $20 \mathrm{~g}$ in $1 \mathrm{~L}$ of distilled water, $\mathrm{pH}$ 7.4). After $1 \mathrm{~h}$ of incubation at room temperature, the multiwell was washed with standard washing buffer, dried and prepared for subsequent analysis.

2) Total RNA extraction: Total RNA (RNAt) was extracted from $0.1 \mathrm{~g}$ of the petiole, with the RNeasy Plant Mini Kit (Qiagen, Hilden, Germany) following the manufacturer's instruction. RNA extracts were re-suspended in $30 \mu$ of RNase-free water and adjusted to approximately 10 $\mathrm{ng} / \mu \mathrm{l}$ using a NanoDrop 1000 spectrophotometer (Thermo Fisher Scientific, MA, USA).

3) Direct crude extract: A slice of $0.4 \mathrm{~mm}$ of the petiole of each sample was directly placed in a $1.5 \mathrm{ml}$ tube containing $0.5 \mathrm{ml}$ of Glycine buffer (EDTA $1 \mathrm{mM}, \mathrm{NaCl} 0.05 \mathrm{M}$, Glycine $0.1 \mathrm{M}$ ), vortexed for $30 \mathrm{sec}$ and heated at $95{ }^{\circ} \mathrm{C}$ for $10 \mathrm{~min}$. Three microliters were used for subsequent analysis.

4) Leaf-disk crude extract: Five fresh-cut petioles were impressed in a $1 \mathrm{~cm}^{2}$ of Hybond $\mathbb{R}-\mathrm{N}+$ hybridisation membrane (GE Healthcare. IL, USA), dried at room temperature for $5 \mathrm{~min}$ and 
278 placed in a $1.5 \mathrm{ml}$ tube containing $0.5 \mathrm{ml}$ of glycine buffer. Tubes were vortexed for $30 \mathrm{sec}$ and 279 heated at $95^{\circ} \mathrm{C}$ for $10 \mathrm{~min}$. Three microliters were used for the subsequent steps.

280 Finally, the 42 sample preparations were tested by DAS-ELISA using a commercial kit of 281 polyclonal antibodies for Tobacco mosaic virus (TMV), which can also detect ToBRFV 282 (AGDIA). The same samples were also tested by end-point RT-PCR using the primers ToBRFV283 F-5722 and ToBRFV-R-6179, and by Real-time RT-PCR-MGB- probe based-method according 284 to the protocols described previously.

285

286

287

288

289

290

291

292

293

294

295

296

297

298

299

300

301

302

303

304

305

306

307

308

309

310

311

312

313

314

315

316

317

In order to understand if the samples with high $\mathrm{Ct}$ value were really positive or false positives, the products obtained with the samples named 1A, 3C, 7R, 8R and 9R using the methods No. 3 and No. 4 of sample preparation were analysed in $2 \%$ agarose gel. The products were purified with the Ultraclean 96 PCR Cleanup Kit (Qiagen, Hilden, Germany) according to the manufacture's instruction and sequenced in both directions using an ABI PRISM 3100 DNA sequence analyser (Applied Biosystems, CA, USA).

\section{Results}

\section{Screening of ToBRFV using end-point RT-PCR}

The end-point RT-PCR analysis showed that 129 of the 360 analysed tomato samples (35.83\%) were positive for ToBRFV. Table 1 reports the number of infected plants per province and data collection. As reported in Table 1, the incidence of ToBRFV was higher in the greenhouses in the provinces of Ragusa and Siracusa, with an infection percentage of $93.3 \%$ and $70 \%$, respectively, than in the greenhouses of the provinces of Agrigento and Caltanissetta that showed a percentage of infected plants of $16.6 \%$ and $6.66 \%$, respectively. Analysing the three surveys performed in the 4 provinces, the virus showed a downward trend. Indeed, Ragusa decreased from $93.3 \%$ of the first sampling to $63.3 \%$ of the third sampling, Siracusa from $70 \%$ to $40 \%$ and Agrigento and Caltanissetta passed from $16.6 \%$ and $6.66 \%$, respectively, to zero.

\section{Mechanical transmission}

Mechanical inoculations successfully transmitted ToB-SIC01/19 in all the plants of Solanum lycopersicum and Capsicum annuum, while no transmission occurred in Solanum melongena. The tomato-inoculated plants did not show any symptom until 22 dpi. Starting from the day 22 , tomato plants showed symptoms that consist in interveinal yellowing, deformation and mosaic in young leaves. In pepper-inoculated plants, the symptoms started at $23 \mathrm{dpi}$ and consisted in slight interveinal yellowing on young leaves and necrosis on the stem. RT-PCR performed at $30 \mathrm{dpi}$ confirmed the presence of ToBRFV in tomato and pepper plants and its absence in eggplants (Table 2).

\section{Full genome sequencing}

The gRNA of the ToBRFV isolate named ToB-SIC01/19 of Sicily was completely sequenced in this study. An RT-PCR synthesis was designed using the genome walking strategy of 
318 overlapping fragments for each adjacent amplified product to avoid the sequencing of different 319 templates (Luria et al., 2017). The accuracy of pure isolate sequencing was assured by the 320 nucleotide sequences comparison of five different clones of each amplicon. The ToB-SIC01/19

321

322

323

324

325

326

327

328

329

330

331

332

333

334

335

336

337

338

339

340

341

342

343

344

345

346

347

348

349

350

351

352

353

354

355

356

357

sequence was assembled with the program Contig implemented with the Vector NTI Advance 11.5 software (Invitrogen, CA, USA) and deposited in GenBank under the Acc. No. MN167466. The genome length of ToB-SIC01/19 consists in 6,391 nucleotides and it was organised as just reported for ToBRFV (Luria et al., 2017). ToB-SIC01/19 showed a percentage identity of 99.8\%, 99.7\%, 99.7\% and 99.7\% with the sequences of TBRFV-P12-3H (Germany; Acc. No. MK133095), TBRFV-P12-3G (Germany; Acc. No. MK133093), Tom1-Jo (Jordan, Acc. No KT383474) and TBRFV-IL (Israel, Acc. No KX619418), respectively.

\section{Primer, Taqman $®$ MGB probe design and protocol optimisation}

The in vitro analysis using Primer-BLAST algorithm of the five primers pairs designed to target the Movement Protein (MP) gene showed no relevant match with other organisms. All the obtained primer pairs were tested by Real-time RT-PCR with SYBR green to identify the primer pair with the lowest $\mathrm{Ct}$ value. Table 3 reports the five designed primer pairs. Between the 5 tested primer pairs, 2 did not give any signal (ToB5461F/ ToB5592R and ToB5461F/

ToB5593R), while the primer pair ToB5520F/ToB5598R showed the lowest $\mathrm{Ct}$ value and was used for the subsequent analyses (Figure $2 \mathrm{~A}$ and $2 \mathrm{~B}$ ).

In vitro hybridisation analysis of the primer pair ToB5520F and ToB5598R against other tobamoviruses was carried out with the program Vector NTI 11.5 program (Invitrogen, CA, USA) and results showed that no relevant matches were identified (see Table S1).

\section{ToBRFV specific Real-time RT-PCR assay with TaqMan MGB probe}

\section{To determine the specificity of the Real-time RT-PCR assay with TaqMan MGB probe, 17} different samples were analysed. As reported in Table 4, the two RNA transcripts gave the most sensitive signal with a $\mathrm{Ct}$ value ranging from 5.0 to 5.1 in four different assays. The total RNA derived from artificially ToBRFV-infected plants gave also positive signal with a $\mathrm{Ct}$ value that ranged from $12.2 \pm 0.2$ to $18.1 \pm 0.1$, while the other tobamoviruses used as outgroups did not give any signal.

\section{Standard curve}

In order to calculate the number of RNA copies and the sensibility threshold of the developed technique, a standard curve was generated using ten-fold serial dilutions of RNA in vitro transcripts (from $10^{10}$ to $10^{1}$ copies) of ToBRFV ToB-SIC01/19 isolate in healthy tomato RNAt. The standard curve covered a wide dynamic range (10 units of concentration) and showed a strong linear relationship, with a correlation coefficient of 0.9997 and $100 \%$ amplification efficiency (Figure 3A and 3B). The Real-time RT-PCR assay and the standard curve enabled the detection of as few as $10^{1}$ ToBRFV RNA copies in tomato extracts and were used to determine the number of RNA copies in the total RNA extracts from the tomato samples collected in four 
358

359

360

361

362

363

364

365

366

367

368

369

370

371

372

373

374

375

376

377

378

379

380

381

382

383

384

385

386

387

388

389

390

391

392

393

394

395

396

397

different areas of Sicily, within the provinces of Agrigento, Caltanissetta, Ragusa and Siracusa. The average $\mathrm{Ct}$ values were within the dynamic range of the standard curve and ranged from 14 to 23 .

\section{Different methods for sample preparation and comparison of different ToBRFV detection techniques}

Four different procedures were evaluated to identify the best method for sample preparation. Forty-two samples (10 per province, ToB-SIC01/19 and a healthy tomato plant) were included. The results obtained with the four different methods of sample preparation were compared with each other and with DAS-ELISA and end-point RT-PCR (Table 5). All the four different methods for sample preparation (immunocapture, total RNA extraction, direct crude extract and leaf-disk crude extract) were effective for ToBRFV detection by Real-time RT-PCR. Analysing the four different procedures, the $\mathrm{Ct}$ value obtained with immunocapture ranged from 16 to 28 , with total RNA extraction from 14 to 23, with leaf-disk crude extract from 17 to 35 and with direct crude extract from 17 to 37 .

Regarding the comparison between Real-time RT-PCR and other techniques, Real-time RT-PCR showed more sensitivity than DAS-ELISA; indeed, 11 samples that gave negative results by DAS-ELISA were positive with Real-time RT-PCR (Table 5). Comparing Real-time RT-PCR to end-point RT-PCR, the two techniques gave the same results with immunocapture and total RNA extraction procedure, while, using direct crude extract and leaf-disk crude extract the end-point RT-PCR was unfit to provide a reliable result.

To confirm the absence of false positives in the Real time RT-PCR assay, the amplification products of the samples named $1 \mathrm{~A}, 3 \mathrm{C}, 7 \mathrm{R}, 8 \mathrm{R}$ and $9 \mathrm{R}$ were analysed in $2 \%$ agarose gel. The samples $7 \mathrm{R}, 8 \mathrm{R}$ and $9 \mathrm{R}$ gave the expected fragment while the samples $1 \mathrm{~A}, 3 \mathrm{C}$, healthy plant (HP) and $\mathrm{H}_{2} \mathrm{O}$ did not show amplification (Figure 4). Sequencing of the samples 7R, 8R and 9R with the sample preparation methods No. 3 and No. 4 confirmed the presence of ToBRFV.

\section{Discussion}

Sicily is one of the Mediterranean Basin regions with the most important tomato production and, due to its geographical position, it represents the main access point for plant material to the European countries. This situation considerably increases the risk of introducing new pathogens into our environments and entails a serious risk for agriculture biosecurity and food production, jeopardising the future of Italian horticulture. The outbreak of Tomato brown rugose fruit virus (ToBRFV) represents a threat due to its multiple transmission methods and to the absence of tomato and peppers resistant varieties. Furthermore, several hybrid tomato varieties presenting Tomato mosaic virus (ToMV) and Tobacco mosaic virus (TMV) Tm-1, Tm-2 and Tm-2 ${ }^{2}$ resistance genes (Pelham, 1966), can be severely affected by ToBRFV, leading to a rapid virus spread in all those areas where tomato is cultivated. To date, the only two available tools to contain ToBRFV worldwide are early diagnosis and the implementation of preventive measures in crop management, which can be a valuable aid in reducing the introduction and subsequent 
398

399

400

401

402

403

404

405

406

407

408

409

410

411

412

413

414

415

416

417

418

419

420

421

422

423

424

425

426

427

428

429

430

431

432

433

434

435

436

437

ToBRFV spread in other countries. Consequently, today there is the need to develop alternative, sensitive and very reliable diagnostic methods for the diagnosis of plant viruses, which are compromising the tomato crops in various Italian and international areas (Hanssen et al., 2010; Puchades et al., 2017; Ferriol et al., 2015, Panno et al., 2014). In the present work a Tomato brown rugose fruit virus isolate, recently found in Sicily (Panno et al., 2019b), was characterised, and a sensitive, specific, rapid and economical method for its detection in infected plants and seeds was developed.

The biological characterisation of the Sicilian ToB-SIC01/19 isolate demonstrated the possibility of mechanical transmission on tomato and pepper plants, as previously reported by Luria and coworkers (2017), while on eggplant it cannot be transmitted. Mechanical transmission is very important because it could simplify genetic improvement activities, in order to constitute new tolerant/resistant germplasm towards ToBRFV. Molecular characterisation showed that the ToBRFV Sicilian isolate ToB-SIC01/19 presents a percentage identity of $99 \%$ with the sequences retrieved in Germany, Jordan and Israel (Menzel et al., 2019; Salem et al., 2016; Luria et al., 2017). Since ToBRFV spread in a few years within the Mediterranean Basin countries and in Central America, the very low level of variability found among isolates supports the hypothesis that the recent introduction in Italy probably occurred through infected seeds. The ability of the virus to transmit trough plant-to-plant contact, manipulation and especially by seeds in overlapping crops cycles, such as tomato intensive cultivation in the greenhouses, facilitated the rapid spread of the virus.

For these reasons, we have developed a quick detection procedure for ToBRFV diagnosis based on Real-time RT-PCR TaqMan MGB probe. This method detects ToBRFV in samples obtained by different preparation procedures. Additionally, the direct crude extracts and leaf-disk crude extracts were successfully used to avoid total RNA extraction, shortening the processing time, allowing the simultaneous analysis of multiple samples and drastically reducing the total cost for single analysis. Its high sensitivity is relevant to minimise false negatives and to obtain correct discrimination of ToBRFV with other viruses belonging to the genus Tobamovirus. Furthermore, the developed technique, associated with the direct crude extract sample preparation, can be used to make in-field diagnosis with a portable device, allowing a considerable saving of time and it could also be used by non-technical personnel.

\section{Conclusions}

The method developed in this work is based on the use of a Real-time RT-PCR TaqMan MGB probe and could represent a good and reliable tool to be included in certification programs. Currently, immuno-enzymatic methods, such as DAS-ELISA, are used in some cases for plant virus diagnosis, but these tests may not be very reliable and give "false negatives", due to the low viral titre of nursery plants and early infections, and to the absence of specific antibodies (Jacobi et al., 1998).

Moreover, the method developed in the present study requires short time and allows the analysis of a great number of samples at the same time, when associated with the use of leaf-disk crude 
438 and direct crude extracts. For this reason, this method could be used as a routine test in the 439 laboratories of vegetable diagnosis. In conclusion, to avoid ToBRFV spread to other Italian and 440 European regions, phytosanitary actions are required, such as correct crop management, more 441 restrictive measures at international borders using rapid, sensitive and economical tools for 442 diagnosis and, more importantly, the development of tomato resistant cultivars that have the 443 ability to tolerate the disease. To date, new tomato cultivars that are tolerant/resistant to ToBRFV

444

445 446

447

448

449

450

451

452

453

454

455

456

457

458

459

460

461

462

463

464

465

466

467

468

469

470

471

472

473

474

475

476

477

are not available. For this reason, the only way to contain this disease globally is the use of a sensitive and economical diagnostic tool such as the Real time RT-PCR method that was developed and described in this paper.

\section{References}

Agri ISTAT, 2017. Available at http://www.agri.istat.it (accessed 07 May 2019).

Alkowni R, Alabdallah O, Fadda Z. 2019. Molecular identification of tomato brown rugose fruit virus in tomato in Palestine. Journal of Plant Pathology, 1-5 DOI: 10.1007/s42161-019-00240-7.

Cambrón-Crisantos JM, Rodríguez-Mendoza J, Valencia-Luna JB, Rangel SA, de Jesús GarcíaÁvila C, López-Buenfil JA. 2018. First report of Tomato brown rugose fruit virus (ToBRFV) in Michoacan, Mexico. Mexican Journal of Phytopathology, 37(1):185-192 DOI: 10.18781/R.MEX.FIT.1810-5.

Davino S, Davino M, Bellardi MG, Agosteo GE. 2008. Pepino mosaic virus and Tomato chlorosis virus causing mixed infection in protected tomato crops in Sicily. Phytopathologia Mediterranea, 47:35-41 DOI: 10.14601/Phytopathol_Mediterr-2542.

Davino S, Napoli C, Dellacroce C, Miozzi L, Noris E, Davino M, Accotto GP. 2009. Two new natural begomovirus recombinants associated with the tomato yellow leaf curl disease co-exist with parental viruses in tomato epidemics in Italy. Virus Research,143:15-23 DOI: 10.1016/j.virusres.2009.03.001.

Davino S, Miozzi L, Panno S, Rubio L, Davino M, Accotto GP. 2012. Recombination profiles between Tomato yellow leaf curl virus and Tomato yellow leaf curl Sardinia virus in laboratory and field conditions: evolutionary and taxonomic implications. Journal of General Virology, 93:2712-2717 DOI: 10.1099/vir.0.045773-0.

Davino S, Panno S, Iacono, G, Sabatino L, D’Anna F, Iapichino G, Olmos A, Scuderi G, Rubio L, Tomassoli L, Capodici G, Martinelli F, Davino M. 2017a. Genetic variation and evolutionary analysis of pepino mosaic virus in Sicily: Insights into the dispersion and epidemiology. Plant Pathology, 66(3):368-375 DOI: 10.1111/ppa.12582. 
478 Davino S, Panno S, Arrigo M, La Rocca M, Caruso AG, Bosco GL. 2017b. Planthology: an 479 Application System for Plant Diseases Management. Chemical Engineering Transactions, 480 58:619-624 DOI: 10.3303/CET1758104.

481

482

483

484

485

486

487

488

489

490

491

492

493

494

495

496

497

498

499

500

501

502

503

504

505

506

507

508

509

510

511

512

513

514

515

516

517

FAO, Food and Agriculture Organization of the United Nations, 2017. Available at http://www.fao.org/faostat/en/\#home (accessed 07 May 2019).

Ferriol I, Rangel EA, Panno S, Davino S, Han CG, Olmos A, Rubio L. 2015. Rapid detection and discrimination of fabaviruses by flow-through hybridisation with genus-and species-specific riboprobes. Annals of applied biology, 167:26-35 DOI: 10.1111/aab.12204.

Fidan H, Sarikaya P, Calis O. 2019. First report of Tomato brown rugose fruit virus on tomato in Turkey.New Disease Reports, 39:18 DOI:10.5197/j.2044-0588.2019.039.018

Hanssen IM, Lapidot M, Thomma BP. 2010. Emerging viral diseases of tomato crops. Molecular plant-microbe interactions, 23(5):539-548 DOI: 10.1094/MPMI-23-5-0539.

King AM, Lefkowitz E, Adams MJ, Carstens EB. 2011. Virus taxonomy: ninth report of the International Committee on Taxonomy of Viruses (Vol. 9). Elsevier.

Jacobi V, Bachand GD, Hamelin RC, Castello JD. 1998. Development of a multi-plex immunocapture RT-PCR assay for detection and differentiation of tomato and tobacco mosaic tobamoviruses. Journal of Virological Methods, 74:167-178 DOI: 10.1016/S01660934(98)00086-X.

Knippers R, Alpert CA. 1999. Recombinant DNA technology. In: Lengeler JW, Drews G, Schlegel HG, ed. Biology of the Prokaryotes, Blackwell Science, Oxford UK, 416-436.

Larkin MA, Blackshields G, Brown NP, Chenna R, McGettigan PA, McWilliam H, Valentin F, Wallace IM, Wilm A, Lopez R, Thompson JD, Gibson TJ, Higgins DG. 2007. Clustal W and Clustal X version 2.0. Bioinformatics, 23:2947-2948 DOI: 10.1093/bioinformatics/btm404.

Levitzky N, Smith E, Lachman O, Luria N, Mizrahi Y, Bakelman H, Sela N, Laskar O, Milrot E, Dombrovsky A. 2019. The bumblebee Bombus terrestris carries a primary inoculum of Tomato brown rugose fruit virus contributing to disease spread in tomatoes. PLOS ONE 14(1): e0210871. DOI:10.1371/journal.pone.0210871

Ling KS, Tian T, Gurung S, Salati R, Gilliard A. 2019. First report of tomato brown rugose fruit virus infecting greenhouse tomato in the US. Plant Disease, 103(6):1439 DOI: 10.1094/PDIS11-18-1959-PDN SUPPLEMENTAL.

PeerJ reviewing PDF | (2019:08:40110:1:1:NEW 18 Sep 2019) 
518

519

520

521

522

523

524

525

526

527

528

529

530

531

532

533

534

535

536

537

538

539

540

541

542

543

544

545

546

547

548

549

550

551

552

553

554

555

556

Luria N, Smith E, Reingold V, Bekelman I, Lapidot M, Levin I, Elad N, Tam Y, Sela N, AbuRas A, Ezra N, Haberman A, Yitzhak L, Lachman O, Dombrovsky A. 2017. A new Israeli Tobamovirus isolate infects tomato plants harboring Tm-2 2 resistance genes. PloS one, 12(1):119 DOI: 10.1371/journal.pone.0170429.

Menzel W, Knierim D, Winter S, Hamacher J, Heupel M, 2019. First report of tomato brown rugose fruit virus infecting tomato in Germany. New Disease Reports, 39:1 DOI: 10.5197/j.20440588.2019.039.001.

Panno S, Davino S, Rubio L, Rangel E, Davino M, García-Hernández J, Olmos A. 2012. Simultaneous detection of the seven main tomato-infecting RNA viruses by two multiplex reverse transcription polymerase chain reactions. Journal of Virological Methods, 186:152-156 DOI: $10.1016 /$ j.jviromet.2012.08.003.

Panno S, Ferriol I, Rangel EA, Olmos A, Cheng-Gui H, Martinelli F, Rubio L, Davino S. 2014. Detection and Identification of Fabavirus species by one step RT-PCR and Multiplex RT-PCR. Journal of Virological Methods, 197:77-82 DOI: 10.1016/j.jviromet.2013.12.002.

Panno S, Caruso AG, Davino S. 2018. The nucleotide sequence of a recombinant tomato yellow leaf curl virus strain frequently detected in Sicily isolated from tomato plants carrying the Ty-1 resistance gene. Archives of virology, 163(3):795-797 DOI: 10.1007/s00705-017-3674-9.

Panno S, Caruso AG, Troiano E, Luigi M, Manglli A, Vatrano T, Iacono G, Marchione S, Bertin S, Tomassoli L, Parrella G, Davino S. 2019a. Emergence of tomato leaf curl New Delhi virus in Italy: estimation of incidence and genetic diversity. Plant Pathology, 68(3):601-608 DOI: 10.1111/ppa.12978.

Panno S, Caruso AG, Davino S. 2019b. First Report of Tomato Brown Rugose Fruit Virus on Tomato Crops in Italy. Plant Disease, 103(6): 1443-1443 DOI: 10.1094/PDIS-12-18-2254-PDN SUPPLEMENTAL.

Pelham J. 1966. Resistance in tomato to tobacco mosaic virus. Euphytica; 15(2):258-67 DOI: 10.1007/BF00022331.

Puchades AV, Carpino C, Alfaro-Fernandez A, Font-San-Ambrosio MI, Davino S, Guerri J, Rubio L, Galipienso L. 2017. Detection of Southern tomato virus by molecular hybridisation. Annals of applied biology, 171: 172-178 DOI: 10.1111/aab.12367. 
557 Salem N, Mansour A, Ciuffo M, Falk BW, Turina M. 2016. A new tobamovirus infecting tomato 558 crops in Jordan. Archives of virology, 161(2):503-506 DOI: 10.1007/s00705-015-2677-7. 559

560 Tiberini A, Davino S, Davino M, Tomassoli L. 2011. Complete sequence, genotyping and 561 comparative analysis of Pepino mosaic virus isolates from Italy. Journal of Plant Pathology 93: 562 437-442 DOI: 10.4454/jpp.v93i2.1199. 


\section{Table $\mathbf{1}$ (on next page)}

Number of ToBRFV-infected tomato plants detected by endpoint RT-PCR. 


\begin{tabular}{lccc}
\hline \multirow{2}{*}{ Province } & \multicolumn{3}{c}{ No. ToBRFV-infected plants / No. Collected plants } \\
\cline { 2 - 4 } & 2018 -October & 2018-December & 2019-February \\
\hline Agrigento & $2 / 30$ & $0 / 30$ & $0 / 30$ \\
Caltanissetta & $5 / 30$ & $0 / 30$ & $0 / 30$ \\
Ragusa & $28 / 30$ & $22 / 30$ & $19 / 30$ \\
Siracusa & $21 / 30$ & $20 / 30$ & $12 / 30$ \\
\hline
\end{tabular}

1 


\section{Table 2 (on next page)}

Mechanical inoculations and symptoms caused by ToB-SIC01/19 isolate on different herbaceous species

iy: interveinal yellowing, myl: mosaic in young leaves, dyl: deformation in young leaves, siyl: slight interveinal yellowing in young leaves, ns: necrosis in the stem. 
1

\begin{tabular}{lccccccc}
\hline & \multicolumn{9}{c}{ Time after inoculaiton (weeks) } & & $\begin{array}{c}\text { \% infected } \\
\text { plants }\end{array}$ \\
\hline Species & 1 & 2 & 3 & 4 & 5 & RT-PCR & \\
\hline Solanum lycopersicum & - & - & - & iy, myl & iy, myl, dyl & + & $100 \%$ \\
Capsicum annum & - & - & - & siy & siyl, ns & + & $100 \%$ \\
Solanum melongena & - & - & - & - & - & - & - \\
\hline
\end{tabular}

2 


\section{Table 3(on next page)}

Forward, reverse primers and probe designed for quantitative RT-qPCR for the detection of Tomato brown rugose fruit virus (ToBRFV).

n.a.: not amplification 
1

\begin{tabular}{|c|c|c|c|c|c|}
\hline Name & $\begin{array}{c}\text { Genomic } \\
\text { position }\end{array}$ & $\begin{array}{l}\text { Referring } \\
\text { sequence }\end{array}$ & Sequence (5'-3') & $\begin{array}{l}\text { Amplicon } \\
\text { Size (bp) }\end{array}$ & $\begin{array}{c}\mathbf{C t} \\
\text { value }\end{array}$ \\
\hline ToB-probe & 5558 & & FAM-GTTTAGTAGTAAAAGTGAGAAT-MGB & & \\
\hline ToB5520F & 5520 & & GTAAGGCTTGCAAAATTTCGTTCG & 101 & 5.0 \\
\hline ToB5598R & 5598 & & CTTTGGTTTTTGTCTGGTTTCGG & & \\
\hline $\begin{array}{l}\text { ToB5498F } \\
\text { ToB5683R }\end{array}$ & $\begin{array}{l}5498 \\
5683\end{array}$ & & $\begin{array}{l}\text { CATGGAAGAAGTCCCGATGT } \\
\text { ATCTGAATCGGCGACGTAAG }\end{array}$ & 205 & 20.8 \\
\hline $\begin{array}{l}\text { ToB5461F } \\
\text { ToB5683R }\end{array}$ & $\begin{array}{l}5461 \\
5683\end{array}$ & KT383474 & $\begin{array}{l}\text { GGCCCATGGAACTATCAGAA } \\
\text { ATCTGAATCGGCGACGTAAG }\end{array}$ & 242 & 25.6 \\
\hline $\begin{array}{l}\text { ToB5461F } \\
\text { ToB5592R }\end{array}$ & $\begin{array}{l}5461 \\
5592\end{array}$ & & $\begin{array}{l}\text { GGCCCATGGAACTATCAGAA } \\
\text { TTGTCTGGTTTCGGCCTATT }\end{array}$ & 151 & n.a. \\
\hline $\begin{array}{l}\text { ToB5461F } \\
\text { ToB5593R }\end{array}$ & $\begin{array}{l}5461 \\
5593\end{array}$ & & $\begin{array}{l}\text { GGCCCATGGAACTATCAGAA } \\
\text { TTTGTCTGGTTTCGGCCTAT }\end{array}$ & 152 & n.a. \\
\hline
\end{tabular}

2

3

4 
Table 4 (on next page)

Real time RT-PCR assay with TaqMan MGB probe. Comparison between ToBRFV and other tobamovirus. 
1

\begin{tabular}{lc}
\hline Virus isolate & Ct \pm SD \\
\hline ToB-SIC1/19-P1 & $18.1 \pm 0.1$ \\
ToB-SIC1/19-P2 & $14.2 \pm 0.3$ \\
ToB-SIC1/19-P3 & $12.2 \pm 0.2$ \\
ToB-SIC1/19-P4 & $13.5 \pm 0.2$ \\
ToB-SIC1/19-P5 & $12.9 \pm 0.1$ \\
Healthy tomato plant & - \\
tRNA1 & $5.1 \pm 0.0$ \\
tRNA2 & $5.0 \pm 0.0$ \\
CGMV & - \\
PaMMV & - \\
PMMV & - \\
TMGMV & - \\
TMV & - \\
ToMMV & - \\
ToMV & - \\
ZGMMV & - \\
\hline
\end{tabular}

2

3

4

5

6 


\section{Table 5 (on next page)}

Analysis of 42 samples using different methods of sample preparation and comparison of real time RT-PCR against DAS-ELISA and endpoint RT-PCR

1* Immunocapture in RT-qPCR multiwell; 2* Total RNA extraction; 3* Leaf-disk crude extract; 4* Direct crude extract 
1

2

3

4

5

6

7

8

9

10

11

12

13

14

15

16

17

18

19

20

21

22

23

24

25

26

27

28

29

30

31

32

33

34

35

36

37

38

39

40

\begin{tabular}{|c|c|c|c|c|c|c|c|c|c|c|}
\hline \multirow[t]{2}{*}{ Province } & \multirow[t]{2}{*}{ Samples } & \multirow[t]{2}{*}{$\begin{array}{l}\text { DAS- } \\
\text { ELISA }\end{array}$} & \multicolumn{4}{|c|}{$\begin{array}{l}\text { RT-PCR end } \\
\text { point }\end{array}$} & \multicolumn{4}{|c|}{$\begin{array}{l}\text { Real time RT-PCR } \\
\text { probe ct value }\end{array}$} \\
\hline & & & $1 *$ & $2 *$ & $3 *$ & $4 *$ & $1 *$ & $2 *$ & $3 *$ & $4^{*}$ \\
\hline \multirow{10}{*}{ Agrigento } & $1 \mathrm{~A}$ & - & - & - & - & - & - & - & - & - \\
\hline & $2 \mathrm{~A}$ & - & - & - & - & - & - & - & - & - \\
\hline & $3 \mathrm{~A}$ & - & - & - & - & - & - & - & - & - \\
\hline & $4 \mathrm{~A}$ & - & - & - & - & - & - & - & - & - \\
\hline & $5 \mathrm{~A}$ & - & - & - & - & - & - & - & - & - \\
\hline & $6 \mathrm{~A}$ & - & - & - & - & - & - & - & - & - \\
\hline & $7 \mathrm{~A}$ & - & - & - & - & - & - & - & - & - \\
\hline & $8 \mathrm{~A}$ & - & - & - & - & - & - & - & - & - \\
\hline & $9 \mathrm{~A}$ & - & + & + & - & - & 18 & 18 & 26 & 26 \\
\hline & $10 \mathrm{~A}$ & - & + & + & - & - & 21 & 19 & 27 & 28 \\
\hline \multirow[t]{10}{*}{ Caltanissetta } & $1 \mathrm{C}$ & - & - & - & - & - & - & - & - & - \\
\hline & $2 \mathrm{C}$ & - & - & - & - & - & - & - & - & - \\
\hline & $3 \mathrm{C}$ & - & - & - & - & - & - & - & - & - \\
\hline & $4 \mathrm{C}$ & - & - & - & - & - & - & - & - & - \\
\hline & $5 \mathrm{C}$ & - & + & + & - & - & 20 & 17 & 30 & 30 \\
\hline & $6 \mathrm{C}$ & - & + & + & - & - & 20 & 17 & 25 & 25 \\
\hline & $7 \mathrm{C}$ & + & + & + & + & + & 22 & 18 & 31 & 32 \\
\hline & $8 \mathrm{C}$ & + & + & + & - & - & 22 & 19 & 31 & 33 \\
\hline & $9 \mathrm{C}$ & - & - & - & & - & - & - & - & - \\
\hline & $10 \mathrm{C}$ & - & + & + & - & - & 24 & 21 & 32 & 32 \\
\hline \multirow[t]{10}{*}{ Ragusa } & $1 \mathrm{R}$ & + & + & + & + & - & 22 & 18 & 30 & 25 \\
\hline & $2 \mathrm{R}$ & + & + & + & + & - & 22 & 18 & 28 & 29 \\
\hline & $3 \mathrm{R}$ & - & + & + & - & - & 26 & 21 & 32 & 32 \\
\hline & $4 \mathrm{R}$ & - & + & + & - & - & 26 & 19 & 33 & 34 \\
\hline & $5 \mathrm{R}$ & - & - & - & - & - & - & - & - & - \\
\hline & $6 \mathrm{R}$ & + & + & + & + & + & 26 & 17 & 31 & 27 \\
\hline & $7 \mathrm{R}$ & + & + & + & + & + & 24 & 17 & 30 & 32 \\
\hline & $8 \mathrm{R}$ & - & + & + & - & - & 28 & 19 & 33 & 34 \\
\hline & 9R & - & + & + & - & - & 28 & 21 & 35 & 37 \\
\hline & $10 \mathrm{R}$ & + & + & + & - & - & 26 & 19 & 32 & 31 \\
\hline \multirow[t]{12}{*}{ Siracusa } & $1 \mathrm{~S}$ & + & + & + & - & - & 26 & 19 & 32 & 32 \\
\hline & $2 \mathrm{~S}$ & + & + & + & - & - & 22 & 18 & 30 & 29 \\
\hline & $3 \mathrm{~S}$ & + & + & + & - & - & 22 & 17 & 31 & 31 \\
\hline & $4 \mathrm{~S}$ & - & + & + & - & - & 26 & 21 & 32 & 33 \\
\hline & $5 \mathrm{~S}$ & - & + & + & - & - & 26 & 23 & 34 & 34 \\
\hline & $6 \mathrm{~S}$ & + & + & + & + & - & 23 & 19 & 32 & 32 \\
\hline & $7 \mathrm{~S}$ & + & + & + & + & + & 20 & 17 & 29 & 29 \\
\hline & $8 \mathrm{~S}$ & - & - & - & - & - & - & - & - & - \\
\hline & $9 \mathrm{~S}$ & - & - & - & - & - & - & - & - & - \\
\hline & $10 \mathrm{~S}$ & - & - & - & - & - & - & - & - & - \\
\hline & ToB-SIC1/19 & + & + & + & - & - & 16 & 14 & 17 & 17 \\
\hline & healthy plant & - & - & - & - & - & - & - & - & - \\
\hline
\end{tabular}


Figure 1

Symptoms of Tomato brown rugose fruits virus

Severe mosaic (A), deformation and necrosis on young leaves (B); discolouration and marbling on fruits (C); necrosis on sepals (D). 


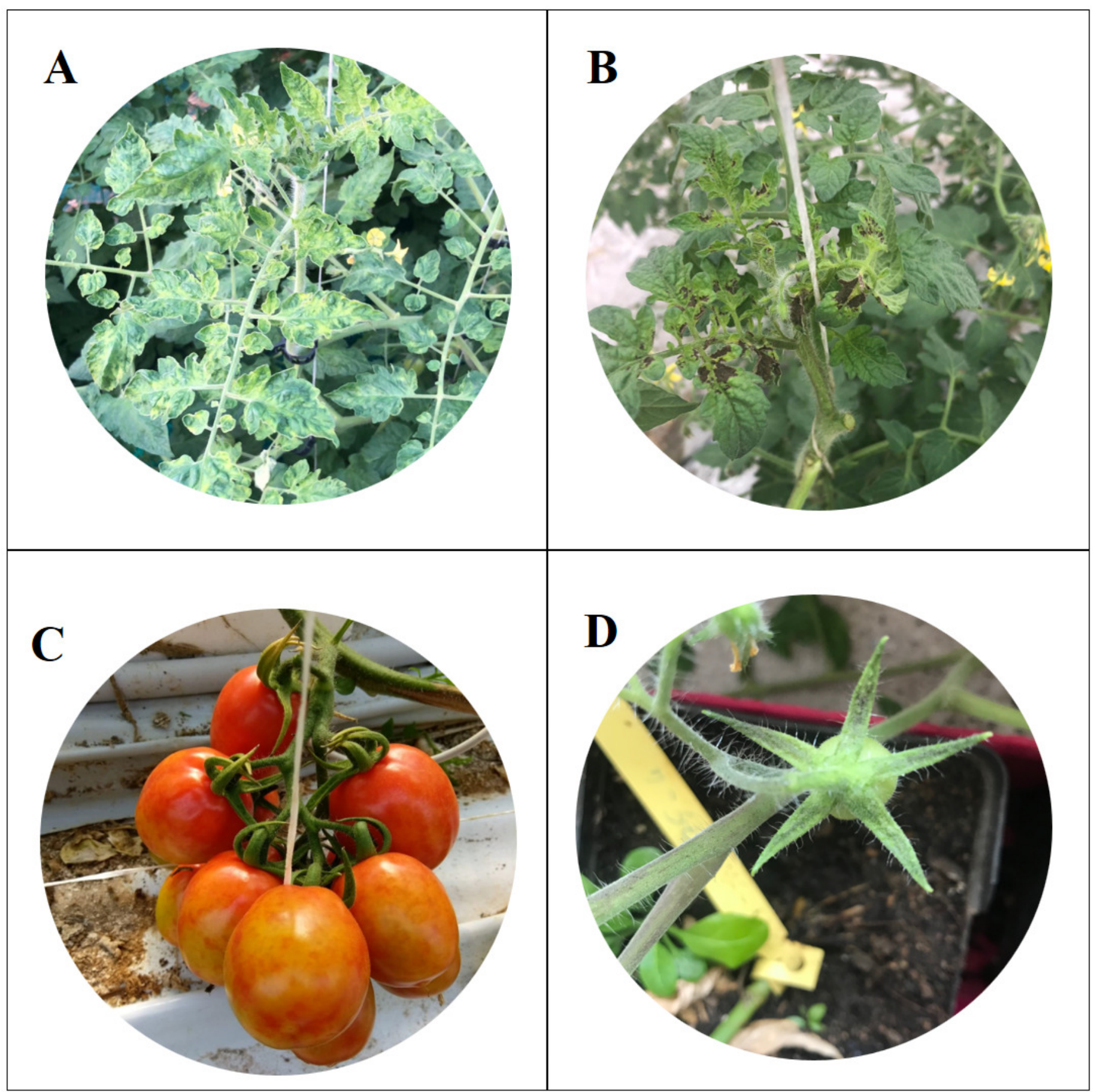




\section{Figure 2}

Real time RT-PCR using the SYBR green method with different primer pairs

Panel A: Amplification curves of real time -RT-PCR using SYBR green with the following primer pairs: p1 (ToB5520F/ToB5598R), p2 (ToB5498F/ToB5683R), p3 (ToB5461F/ToB5683R), p4 (ToB5461F/ToB5592R) and p5 (ToB5461F/ToB5593R). Primer pairs p4 and p5 did not show amplification, while primer pair A showed the lowest $\mathrm{Ct}$ value. Panel B: Melting curves of the amplification curves previously obtained with the 5 different primer pairs. 

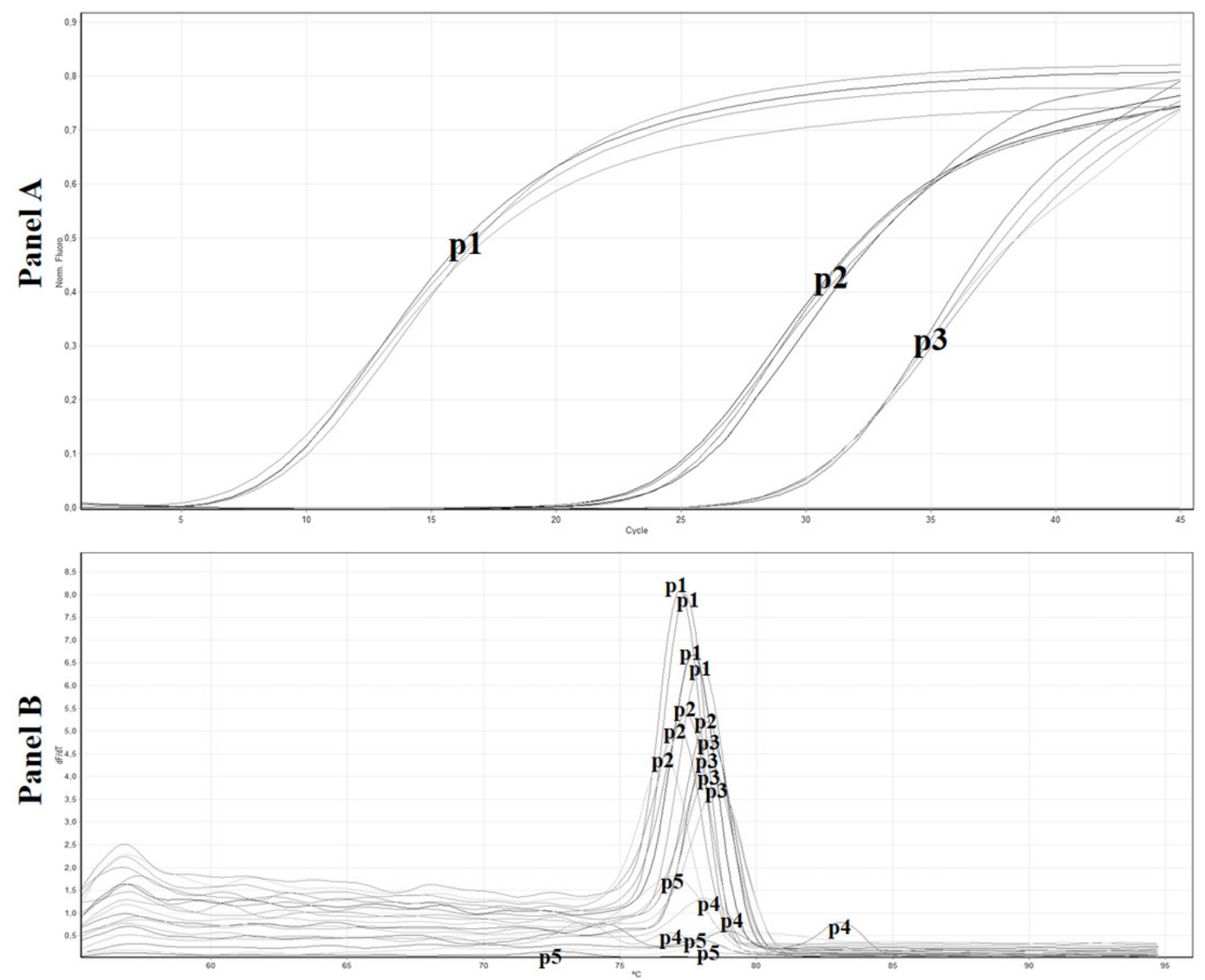


\section{Figure 3}

Standard curve and linear regression of real time RT-PCR.

Panel A: Standard curves prepared with ten-fold serial dilutions of in vitro-synthesised RNA transcripts from ToBRFV ToB-SIC01/19 isolate using real time RT-PCR with TaqMan MGB probe. Panel B: Curves were generated by linear regression analysis, plotting the $\mathrm{Ct}$ value in the $Y$ axis vs the logarithm of the starting RNA dilutions in the $X$ axis. Each plotted point represents the mean $\mathrm{Ct}$ value that was calculated from the four different experiments with two replicates. The calculated correlation coefficient $\left(\mathrm{R}^{2}\right)$ and amplification efficiency (E) values are indicated in each curve. 

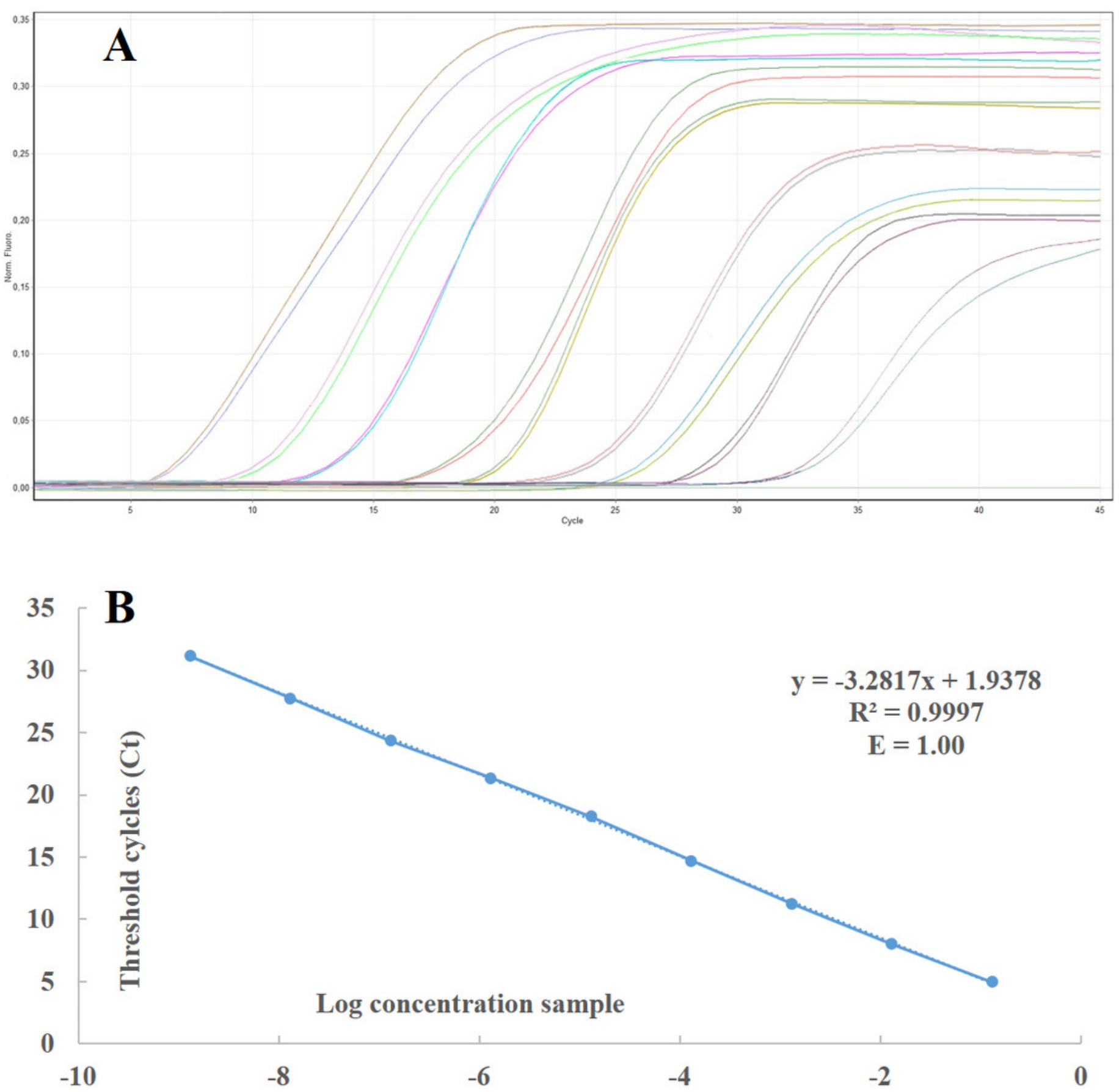


\section{Figure 4}

Comparison of samples showing high Ct value in real timeRT-PCR with electrophoretic gel

Panel A: Amplification curves obtained with the primer pair ToB5520F/ToB5598R and ToBprobe-5558 probe of the samples reported in table No. 5, which are named: tRNA1, 1A, 3C, $\mathrm{HP}$ (Healthy Plant), $\mathrm{H}_{2} \mathrm{O}, 7 \mathrm{R}, 8 \mathrm{R}$ and $9 \mathrm{R}$. The $3^{*}$ and $4 *$ indicated the different samples preparation methods that are reported in table No. 5. Panel B: Electrophoretic $2 \%$ agarose gel of real-time RT-PCR products. M: 100 bp marker (Thermo Fischer Scientific). 

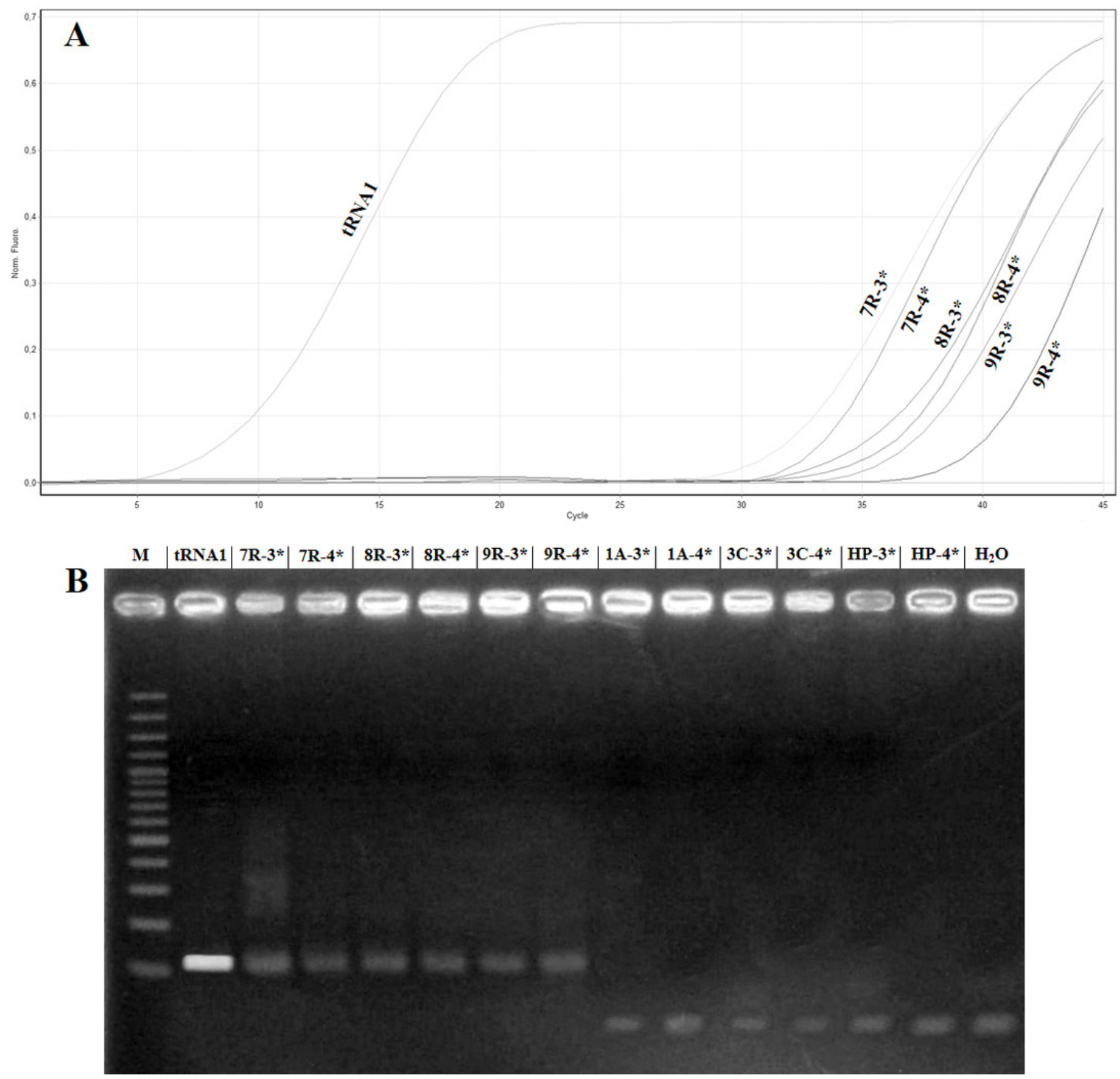